\title{
Specific inhibition of the endothelin A receptor with ZD4054: clinical and pre-clinical evidence
}

\author{
CD Morris",', A Rose', J Curwen', AM Hughes', DJ Wilson' and DJ Webb \\ 'AstraZeneca, Alderley Park, Macclesfield, Cheshire SKIO 4TF, UK; ${ }^{2}$ University of Edinburgh, Western General Hospital, Edinburgh, UK
}

\begin{abstract}
Activation of the endothelin $\mathrm{A}$ receptor $\left(E \mathrm{E}_{\mathrm{A}}\right)$ by endothelin-I (ET-I) mediates events that regulate mitogenesis, apoptosis, angiogenesis and metastasis in tumours. Specific blockade of $\mathrm{ET}_{\mathrm{A}}$ may have anticancer effects, while retaining beneficial endothelin $\mathrm{B}$ receptor $\left(\mathrm{ET}_{\mathrm{B}}\right)$-mediated effects such as apoptosis and clearance of $\mathrm{ET}$ - I. ZD4054 is an orally active, specific $\mathrm{ET}_{\mathrm{A}}$ antagonist in clinical development. In receptor-binding studies, ZD4054 specifically bound to $\mathrm{ET}_{\mathrm{A}}$ with high affinity; no binding was detected at $\mathrm{ET}_{\mathrm{B}}$. In a randomised placebo-controlled trial in eight healthy volunteers, a single oral dose of ZD4054 reduced forearm vasoconstriction in response to brachial artery infusion of $E T-1$, thus providing clinical evidence of $E T_{A}$ blockade. $E T_{B}$ blockade was assessed in an ascending, single-dose, placebo-controlled trial in 28 volunteers. For all doses of ZD4054, mean plasma ET-I concentrations measured at 4 and $24 \mathrm{~h}$ were within the placebo reference range (a rise in $E T-I$ would indicate $\mathrm{ET}_{\mathrm{B}}$ blockade) and there was no evidence of dose-related changes. These data confirm the specificity of $Z D 4054$ for $E_{A}$, with no activity at $E T_{B}$ in a clinical or preclinical setting. As a result of this specificity, ZD4054 has the potential to block multiple $\mathrm{ET}_{\mathrm{A}}$-induced pathological processes, while allowing beneficial $\mathrm{ET}_{\mathrm{B}}$-mediated processes to continue, which may, in turn, lead to an effective cancer therapy.
\end{abstract}

British Journal of Cancer (2005) 92, 2148-2152. doi:1 0.1038/s.bjc.6602676 www.bjcancer.com

(C) 2005 Cancer Research UK

Keywords: endothelin A receptor; receptor specificity; cancer; volunteer studies; ZD4054

There is accumulating evidence to suggest that endothelins, particularly endothelin-1 (ET-1), have a role in regulating the growth and proliferation of tumours (Nelson et al, 2003). ET-1, produced by tumour cells, exerts its effects primarily by binding to G-protein-coupled receptors on the cell surface (endothelin A receptor $\left(\mathrm{ET}_{\mathrm{A}}\right)$ and $\mathrm{B}$ receptor $\left(\mathrm{ET}_{\mathrm{B}}\right)$ ) (Nelson et al, 2003) and modifying the effects of other growth factors (Nelson et al, 1995).

Binding of ET-1 to $\mathrm{ET}_{\mathrm{A}}$ and $\mathrm{ET}_{\mathrm{B}}$ causes distinct and opposing effects on cell growth and survival. In most cells, activation of $\mathrm{ET}_{\mathrm{A}}$ promotes cell growth (Nelson et al, 2003), whereas activation of $\mathrm{ET}_{\mathrm{B}}$ induces cell death via apoptosis (Okazawa et al, 1998). In addition, binding of ET-1 to $\mathrm{ET}_{\mathrm{B}}$ results in clearance of ET-1 from the circulation. Overexpression of $\mathrm{ET}_{\mathrm{A}}$ has been reported in a variety of human tumours and human cancer cell lines, including the prostate, ovary, lung, colon, kidney, cervix and bone (Nelson et al, 2003). Conversely, $\mathrm{ET}_{\mathrm{B}}$ expression is reduced in the majority of solid tumours, but is still evident (Nelson et al, 2003). The balance of $\mathrm{ET}_{\mathrm{A}}$ and $\mathrm{ET}_{\mathrm{B}}$ activation in tumour cells appears to be important in progression of most cancers (Nelson et al, 2003), especially prostate cancer (Kopetz et al, 2002). Increased expression of $\mathrm{ET}_{\mathrm{A}}$ relative to $\mathrm{ET}_{\mathrm{B}}$ could contribute to increased tumour cell survival and growth.

Activation of $\mathrm{ET}_{\mathrm{A}}$ by ET-1 is reported to result in a number of events involved in the malignant process, including regulating mitogenesis, apoptosis, angiogenesis and tumour metastasis. It triggers a signalling cascade involving growth factors such as

* Correspondence: C Morris; E-mail: Clive.morris@astrazeneca.com Received 9 February 2005; revised 24 May 2005; accepted 24 May 2005 epidermal growth factor and insulin-like growth factor-1 (Pirtskhalaishvili and Nelson, 2000), kinases including protein kinase C and mitogen-activated protein kinase (Bagnato et al, 1997; Bagnato and Catt, 1998), and induction of immediate-early response genes ( $c$-fos, $c$-jun and $c-m y c$ ) that promote cell growth and mitogenesis (Battistini et al, 1993). Additionally, apoptosis induced by cytotoxic agents is inhibited (Del Bufalo et al, 2002) and angiogenesis promoted (via a vascular endothelial growth factor (VEGF)-mediated mechanism) by activation of $\mathrm{ET}_{\mathrm{A}}$ (Spinella et al, 2002; Bagnato and Spinella, 2003). The role of $\mathrm{ET}_{\mathrm{A}}$ in mediating increased proliferation, resistance to apoptosis and survival of tumour cells, and increased angiogenesis - a process central to tumour growth - makes $\mathrm{ET}_{\mathrm{A}}$ an attractive target for cancer therapy.

In addition to a role in growth and survival of primary tumours, $\mathrm{ET}_{\mathrm{A}}$ is an attractive target to prevent the spread and survival of tumour metastases. Activation of $\mathrm{ET}_{\mathrm{A}}$ induces the expression and activation of tumour proteases (matrix metalloproteinases and urokinase plasminogen activator) that facilitate tumour spread and metastasis (Rosanò et al, 2001). Furthermore, activation of $\mathrm{ET}_{\mathrm{A}}$ leads to proliferation of osteoblasts, bone remodelling and release of growth factors that stimulate survival and growth of metastatic tumour cells (Nelson et al, 1999) within prostate cancer metastases in bone. These findings have led to extensive research into the endothelin receptors as a target for anticancer therapies.

Specific blockade of $\mathrm{ET}_{\mathrm{A}}$ may offer an effective cancer therapy, since the anticancer effects of endothelin antagonists appear to be mediated via $\mathrm{ET}_{\mathrm{A}}$ blockade. In contrast, antagonism of $\mathrm{ET}_{\mathrm{B}}$ may lead to undesirable effects, such as inhibition of apoptosis and reduced clearance of ET-1. Thus, an agent with activity purely at 
the $\mathrm{ET}_{\mathrm{A}}$ (i.e. a specific $\mathrm{ET}_{\mathrm{A}}$ antagonist) would be desirable in an oncology setting. Atrasentan (Abbott Laboratories) is a selective $\mathrm{ET}_{\mathrm{A}}$ antagonist currently in development which, while selectively binding to $\mathrm{ET}_{\mathrm{A}}$, also exhibits antagonism of $\mathrm{ET}_{\mathrm{B}}$ (Nelson, 2003), leading to increased plasma ET-1 levels (Carducci et al, 2002; Nelson, 2003). These findings are consistent with the binding affinities reported for atrasentan $\left(0.034\right.$ and $63.3 \mathrm{nM}$ for $\mathrm{ET}_{\mathrm{A}}$ and $\mathrm{ET}_{\mathrm{B}}$, respectively). ZD4054 (AstraZeneca) is an orally active $\mathrm{ET}_{\mathrm{A}}$ antagonist in early clinical development for the treatment of cancer, which has recently been granted fast-track status by the FDA. The synthesis and molecular characterisation of ZD4054, a nonpeptide $\mathrm{ET}_{\mathrm{A}}$ antagonist, has been described previously (Bradbury et al, 1997). ZD4054 binds to $\mathrm{ET}_{\mathrm{A}}$ with high affinity and has no detectable affinity for $\mathrm{ET}_{\mathrm{B}}$. In preclinical studies, ZD4054 specifically inhibits $\mathrm{ET}_{\mathrm{A}}$-mediated antiapoptotic effects, but not $\mathrm{ET}_{\mathrm{B}}$-mediated proapoptotic effects in human smooth muscle cells (Curtis et al, 2004; Dreicer et al, 2005), blocks $\mathrm{ET}_{\mathrm{A}}$-mediated activation of $\mathrm{p} 44 / 42$ mitogen-activated protein kinase in murine osteoblast cells and inhibits ET-1 induced proliferation of human immature pre-osteoblast cells (Curtis et al, 2005). Importantly, ZD4054 inhibits growth of tumour xenografts in mice and enhances the cytotoxicity of paclitaxel in ovarian carcinoma in vitro and in vivo (Rosanò et al, 2005). This paper reports the results of studies that were conducted to confirm the specificity of ZD4054 for $\mathrm{ET}_{\mathrm{A}}$ in a clinical setting.

\section{MATERIALS AND METHODS}

\section{Receptor-binding assays}

The inhibition by ZD4054 (varying concentrations) of ${ }^{125}$ iodineET-1 binding to cloned human $\mathrm{ET}_{\mathrm{A}}$ and $\mathrm{ET}_{\mathrm{B}}$ was assessed using standard radioligand-binding techniques. Human recombinant $\mathrm{ET}_{\mathrm{A}}$ or $\mathrm{ET}_{\mathrm{B}}$ was expressed in mouse erythroleukaemic cells, and cell membranes prepared for competitive binding studies using ${ }^{125}$ iodine-ET-1 as the radioligand. Incubations were carried out in triplicate in the presence of ZD4054, $100 \mathrm{pm}$ to $100 \mu \mathrm{M}$ in half-log increments, and inhibition of ET-1 binding was expressed as the geometric mean $\mathrm{pIC}_{50}$ value (concentration to inhibit $50 \%$ of binding) with a 95\% confidence interval (CI). The affinity of ZD4054 for cloned human $\mathrm{ET}_{\mathrm{A}}$ was also assessed - using the equation of Cheng and Prusoff (1973) to determine the equilibrium dissociation constant $\left(K_{\mathrm{i}}\right)$ - in a further receptor-binding screen utilising a greater number of concentration-response curves determined in three separate studies.

\section{Healthy volunteer study of forearm vasoconstriction to assess interaction with $\mathrm{ET}_{\mathrm{A}}$}

ET-1 causes vasoconstriction predominantly by activation of $\mathrm{ET}_{\mathrm{A}}$ on vascular smooth muscle (Spratt et al, 2001). Therefore, inhibition of ET-1-induced vasoconstriction, measured by venous occlusion plethysmography (Wilkinson and Webb, 2001), would provide clinical evidence of $\mathrm{ET}_{\mathrm{A}}$ blockade.

A single-dose, double-blind, placebo-controlled randomised trial was undertaken in eight healthy adult male volunteers to study the effect of ZD4054 on ET-1-mediated forearm vasoconstriction. All volunteers had previously demonstrated a mean $25-$ $75 \%$ reduction in forearm blood flow (measured using standard strain gauge venous occlusion plethysmography) in response to a 120 -min brachial artery infusion of ET-1. The effects of two oral doses of ZD4054 (10 and $30 \mathrm{mg}$ ) on ET-1-induced vasoconstriction were compared with placebo. Over nonconsecutive days, each volunteer received both doses of ZD4054 and placebo. The study was limited to two active doses and placebo due to the invasive nature and high technical difficulty of the brachial artery infusions and forearm vasoconstriction assessment. A 120-min brachial artery infusion of ET-1 $\left(2.5 \mathrm{pmol} \mathrm{min}{ }^{-1}\right)$ was given to resting subjects, commencing $2 \mathrm{~h}$ after dosing with ZD4054 or placebo. The degree of forearm vasoconstriction measured between 90 and $120 \mathrm{~min}$ of the infusion (at 10-min intervals over a 30 -min period) was compared between dose groups. The summary measure for statistical analyses was the percentage change in forearm blood flow. This measure was derived from the change from baseline (immediately prior to ET-1 infusion) in the mean area under the effect curve (forearm blood flow response) from 90 to $120 \mathrm{~min}$ $\left(\right.$ AUEC $\left._{90-120}\right)$ relative to the noninfused arm for each volunteer at each dose level $v s$ placebo. Previous studies have shown that AUEC $_{90-120}$ represents the most sensitive measure of $\mathrm{ET}_{\mathrm{A}}$ antagonism as ET-1-induced vasoconstriction is usually maximal after 90 min (Strachan et al, 2002). Treatment and dose effects were compared using analysis of variance (ANOVA), fitting effects for subject and dose level.

\section{Healthy volunteer study of plasma ET-1 levels to assess interaction with $\mathrm{ET}_{B}$}

A randomised, ascending, single-dose, double-blind, placebocontrolled study was undertaken in 28 healthy adult male volunteers. Oral doses of ZD4054 evaluated were 2.5, 10, 20, 30, $60,120,150$ and $240 \mathrm{mg}$, with dose escalation continued based on tolerability until the maximum tolerated dose had been defined. The planned dose escalation sequence was from 120 to $240 \mathrm{mg}$ ZD4054. However, the $240 \mathrm{mg}$ dose was not tolerated; so the dose of $150 \mathrm{mg}$ ZD4054 was investigated to further define the maximum tolerated dose. Volunteers were randomised approximately $3: 1$ to ZD4054 or placebo on each study day. Each cohort of volunteers was dosed consecutively on three separate study days, with a minimum of 14 days between doses in the same group. Doses of ZD4054 given were: group $1(n=9) 2.5,60$ and $150 \mathrm{mg}$; group 2 $(n=9)$ 10, 20 and $120 \mathrm{mg}$; group $3(n=10) 30$ and $240 \mathrm{mg}$. Blood samples were collected for measurement of plasma ET-1 (and its precursor, Big-ET-1), at baseline and at 4 and $24 \mathrm{~h}$ post-dose. An increase in ET-1 was taken as evidence of $\mathrm{ET}_{\mathrm{B}}$ blockade. ET-1 and big ET were extracted from plasma using an acetic acid extraction technique described by Rolinski et al (1994). Concentrations of ET-1 and big ET-1 in the extract were determined by radioimmunoassay using a methodology based on commercially available assay kits (Peninsula Laboratories Inc., San Carlos, CA, USA). Briefly, $100 \mu \mathrm{l}$ of standard, sample or control was incubated with the appropriate antibody overnight. Samples were incubated with a known concentration of radio-labelled ET-1 or big ET-1 for a further $16 \mathrm{~h}$ and the immune complexes were precipitated with Amerlex $^{\mathrm{TM}}$ (Amersham Plc, Amersham, UK) donkey anti-rabbit antibody. The sensitivities of the assays, defined as two standard deviations above the zero binding, were $0.25 \mathrm{pg} \mathrm{ml}^{-1}$ for ET-1 and $1 \mathrm{pg} \mathrm{ml}^{-1}$ for big ET-1.

Both clinical studies were approved by an Independent Ethics Committee and all subjects gave written informed consent. The study was performed in accordance with ethical principles originating in the Declaration of Helsinki and consistent with ICH/Good Clinical Practice, applicable regulatory requirements and AstraZeneca's policy on bioethics.

\section{RESULTS}

\section{Receptor-binding assays}

ZD4054 potently inhibited the binding of ${ }^{125}$ iodine-ET- 1 to cloned human $\mathrm{ET}_{\mathrm{A}}$ expressed in mouse erythroleukaemic cells, showing that ZD4054 has high affinity for $\mathrm{ET}_{\mathrm{A}}$. The $\mathrm{pIC}_{50}$ for ZD4054 at the $\mathrm{ET}_{\mathrm{A}}$ (geometric mean) was $8.27 \mathrm{~nm}(95 \% \mathrm{CI}: 8.23,8.32 \mathrm{nM})(n=4)$. Displacement curves were normal, with slopes close to unity. In the multi-receptor binding screen, $\mathrm{pIC}_{50}$ values for $\mathrm{ZD} 4054$ at $\mathrm{ET}_{\mathrm{A}}$ 
were 22, 27 and $13 \mathrm{~nm}$ (mean value $21 \mathrm{~nm}$ ) (Table 1 ). The $K_{\mathrm{i}}$ values measured in the same studies were 13,17 and $8 \mathrm{~nm}$ (mean value $13 \mathrm{~nm})$.

In contrast, ZD4054 had no measurable affinity for cloned human $\mathrm{ET}_{\mathrm{B}}$, with a mean displacement of only $1.2 \pm 0.7 \%(n=3)$ of ${ }^{125}$ iodine-ET-1 at a concentration of $100 \mu \mathrm{M}$ ZD4054. This level of displacement is within the background range and is likely to be caused by assay variability. In the multi-receptor-binding screen, ZD4054 was inactive at $\mathrm{ET}_{\mathrm{B}}$ at a concentration of $10 \mu \mathrm{M}$ (Table 1).

These data show that ZD4054 is a high-affinity ligand for $\mathrm{ET}_{\mathrm{A}}$, with no measurable affinity for $\mathrm{ET}_{\mathrm{B}}$.

\section{Healthy volunteer study of forearm vasoconstriction to assess interaction with $\mathrm{ET}_{\mathrm{A}}$}

In volunteers given placebo, forearm blood flow was reduced by approximately $40 \%$ in response to brachial artery infusion of ET-1.

Table I Effect of ZD4054 on the binding of ${ }^{125}$ I-ET-I to cloned human $E T_{A}$ and $E T_{B}$

\begin{tabular}{llc}
\hline & ZD4054 binds specifically to $\mathbf{E T}_{\mathbf{A}}$ \\
\hline & pIC $_{\mathbf{5 0}}$ & Standard error \\
\hline$E T_{\mathrm{A}}$ & $21 \mathrm{nM}$ & \pm 4 \\
$\mathrm{ET}_{\mathrm{B}}$ & Not detected $(>10 \mu \mathrm{M})$ & \\
\hline
\end{tabular}

$\mathrm{plC}_{50}=$ concentration required to inhibit $50 \%$ of binding.
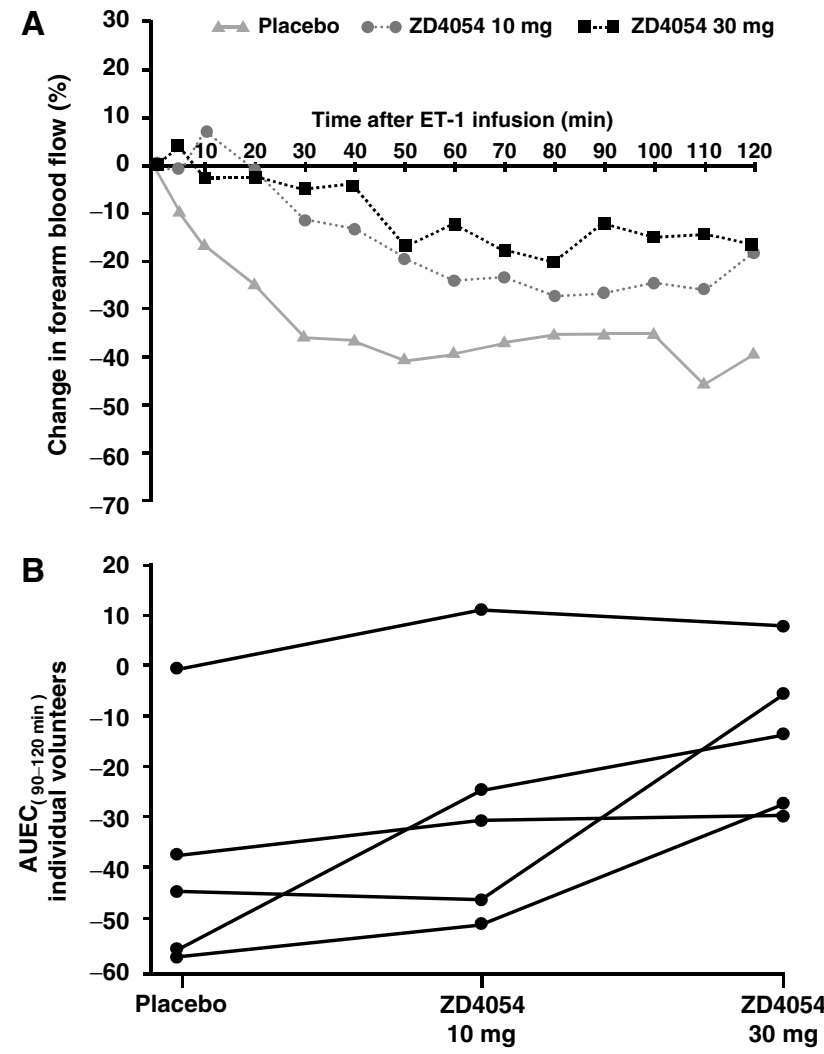

$\mathrm{AUEC}_{90-120 \mathrm{~min}}=$ mean area under the effect curve from 90 to $120 \mathrm{~min}$

Figure I Administration of ZD4054 (10 and $30 \mathrm{mg}$ ) to healthy volunteers inhibits ET-I induced vasoconstriction. (A) Mean change in forearm blood flow and $(\mathbf{B})$ individual $\operatorname{AUEC}_{(90-120 \mathrm{~min})}$ by dose level for five volunteers.
ZD4054 inhibited this response to ET-1 (Figure 1A). The mean $\mathrm{AUEC}_{(90-120 \mathrm{~min})}$ corresponding to the forearm blood flow for each dose and placebo is shown in Table 2 and the $\operatorname{AUEC}_{(90-120 \text { min) }}$ for individual patients at each dose level is shown in Figure $1 \mathrm{~B}$ to illustrate the variability between individual volunteers. Administration of ZD4054 (10 or $30 \mathrm{mg}$; combined data) produced a statistically significant absolute reduction in vasoconstriction of $18.8 \%(P=0.021)$ when compared to placebo. Pairwise comparison showed that administration of ZD4054 (30 mg) produced a statistically significant absolute reduction in vasoconstriction of $23.7 \%(P=0.0125)$, representing a $63 \%$ decrease in vasoconstriction relative to placebo. ZD4054 $(10 \mathrm{mg})$ resulted in a numerical decrease in vasoconstriction compared with placebo, which did not reach statistical significance $(P=0.10)$. Peak plasma concentrations were reached by 1.75 and $2.5 \mathrm{~h}$ post-dosing and the mean plasma half-life of ZD4054 was 9.10 and $9.65 \mathrm{~h}$ for the 10 and $30 \mathrm{mg}$ doses, respectively.

These results provide evidence that $\mathrm{ZD} 4054$ is an $\mathrm{ET}_{\mathrm{A}}$ antagonist in healthy volunteers.

Table 2 Mean forearm blood flow (FBF) $\mathrm{AUEC}_{(90-120 \mathrm{~min})}$

\begin{tabular}{|c|c|c|c|}
\hline Treatment & $\mathbf{N}$ & FBF AUEC $90-120 \mathrm{~min}$ mean (\%) & $90 \% \mathrm{Cl}$ \\
\hline Placebo & 5 & -39.5 & $-61.6,-17.4$ \\
\hline ZD4054 (30 mg) & 6 & -14.7 & $-26.3,-3.0$ \\
\hline ZD4054 (10 mg) & 6 & -24.5 & $-44.3,-4.7$ \\
\hline
\end{tabular}

ET-I $\left(2.5 \mathrm{pmol} \mathrm{min}^{-1}\right)$ was administered over $2 \mathrm{~h}$ after treatment with placebo or ZD4054. AUEC $90-120 \mathrm{~min}=$ mean area under the effect curve from 90 to $120 \mathrm{~min}$.
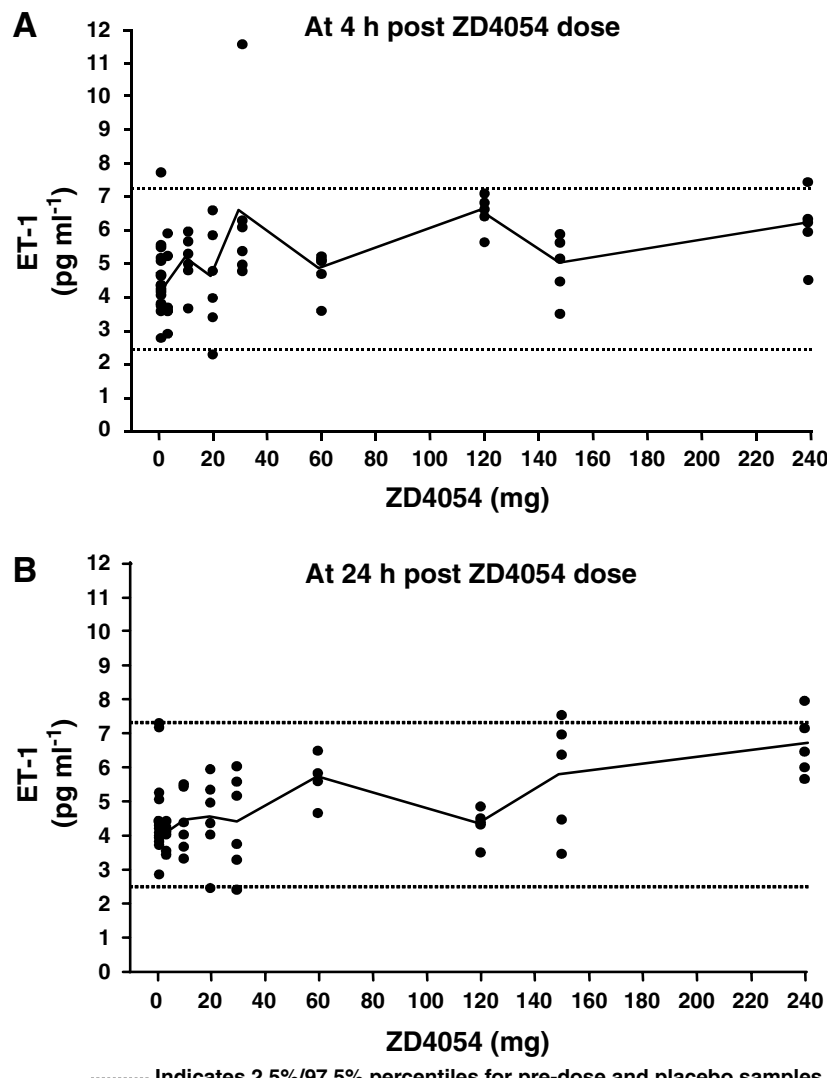

Figure 2 Administration of ZD4054 at doses upto $240 \mathrm{mg}$ has no effect on plasma ET- I concentrations in healthy volunteers at $4(\mathbf{A})$ and $24 \mathrm{~h}(\mathbf{B})$ post-dose. Individual and mean data are shown. 


\section{Healthy volunteer study of plasma ET-1 levels to assess interaction with $\mathrm{ET}_{\mathrm{B}}$}

Following administration of ZD4054 (2.5-240 mg), mean values for plasma ET-1 were within the placebo range at both 4 and $24 \mathrm{~h}$ post-dose (Figures $2 \mathrm{~A}$ and $\mathrm{B}$ ). The placebo range was defined by the 2.5 and $97.5 \%$ percentiles of the pre-dose and placebo (drug naïve) samples. Within this study, ZD4054 was well-tolerated at single doses up to and including $120 \mathrm{mg}$; dose escalation was limited by headache, nausea and vomiting. Based on a rise in mean ET-1 values (Figures 2A and B) or percentage change from baseline (data not shown), there was no evidence of a dose-related response across the 2.5-240 mg (twice the maximum well-tolerated dose) dose range tested. Since peak plasma concentrations of ZD4054 were reached by approximately $2 \mathrm{~h}$ post-dose, any impact on ET-1 clearance and plasma concentration of ET-1 can be expected to be detectable at $4 \mathrm{~h}$ post-dose. However, no consistent profile was observed when comparing the 4 - and 24 -h time points at each dose (Figures 2A or B). Similarly, there was no evidence of an increase in levels of Big ET-1, the precursor for ET-1 (data not shown).

These data, showing the inability of ZD4054 to alter plasma concentrations of ET-1 (a biomarker of $\mathrm{ET}_{\mathrm{B}}$ blockade in vivo (Strachan et al, 1999)) in healthy volunteers, demonstrate the specificity of $\mathrm{ZD} 4054$ for $\mathrm{ET}_{\mathrm{A}}$ in a clinical setting.

\section{DISCUSSION}

Studies have shown that activation of $\mathrm{ET}_{\mathrm{A}}$ by ET-1 results in a number of events that promote cell growth and mitogenesis (Battistini et al, 1993; Bagnato et al, 1997; Bagnato and Catt, 1998; Pirtskhalaishvili and Nelson, 2000), inhibit apoptosis induced by cytotoxic agents (Del Bufalo et al, 2002) and facilitate angiogenesis (Spinella et al, 2002; Bagnato and Spinella, 2003). Activation of $\mathrm{ET}_{\mathrm{A}}$ by ET-1 also induces tumour proteases that facilitate tumour metastasis (Rosanò et al, 2001), and causes proliferation of osteoblasts, bone remodelling and release of growth factors that stimulate survival and growth of metastatic tumour cells (Nelson et al, 1999). As a result, $\mathrm{ET}_{\mathrm{A}}$ is an attractive target for cancer therapy. Specific blockade of $\mathrm{ET}_{\mathrm{A}}$ has the potential to mediate anticancer effects, while allowing beneficial effects such as apoptosis and clearance of ET-1 that are mediated by $\mathrm{ET}_{\mathrm{B}}$ to proceed.

Results of the in vitro binding studies presented here show ZD4054 to be a potent and specific $\mathrm{ET}_{\mathrm{A}}$ antagonist, exhibiting high-affinity binding to $\mathrm{ET}_{\mathrm{A}}$, with no measurable affinity for $\mathrm{ET}_{\mathrm{B}}$ at a concentration of $10 \mu \mathrm{m}$. These results are consistent with previously reported molecular characterisation (Bradbury et al, 1997), and the results of functional assays showing that ZD4054 specifically inhibited $\mathrm{ET}_{\mathrm{A}}$-mediated antiapoptotic effects, but not $\mathrm{ET}_{\mathrm{B}}$-mediated proapoptotic effects, in human and rat smooth muscle cells (Curtis et al, 2004; Dreicer et al, 2005).

The experimental forearm vasoconstriction model is currently accepted as a standard technique for the investigation of vascular pharmacology and the impact of intra-arterial drug infusion in man (Wilkinson and Webb, 2001). Results using this model show ZD4054 to be a pharmacologically active $\mathrm{ET}_{\mathrm{A}}$ antagonist, acting in a dose-related manner to reduce ET-1-induced vasoconstriction. This vasoconstriction is mediated primarily by ET-1 selective, vascular smooth muscle $\mathrm{ET}_{\mathrm{A}}$ (Spratt et al, 2001). Although these results clearly demonstrate $\mathrm{ET}_{\mathrm{A}}$ antagonism in vivo, they do not give any information regarding the affinity of ZD4054 for $\mathrm{ET}_{\mathrm{B}}$. Thus, a further volunteer study was undertaken to explore the specificity of ZD4054 for $\mathrm{ET}_{\mathrm{A}}$.

In healthy volunteers, the concentration of circulating ET-1 has been established as a biomarker of $\mathrm{ET}_{\mathrm{B}}$ blockade in vivo (Strachan et al, 1999). In this setting, a rise in plasma ET-1, particularly without an accompanying rise in Big ET-1, indicates $\mathrm{ET}_{\mathrm{B}}$ inhibition. In the healthy volunteer study reported here, no evidence of ZD4054-induced $\mathrm{ET}_{\mathrm{B}}$ inhibition was detected; mean plasma levels of ET-1, at all doses of ZD4054, were within the placebo range at 4 and $24 \mathrm{~h}$ post-dose. No clinically significant rise in plasma ET-1 was observed when ZD4054 was given at doses up to $240 \mathrm{mg}$ (twice the maximum tolerated dose). Furthermore, there was no evidence of a dose-related response based on a rise in mean ET-1 or percentage change from baseline. These data provide evidence that single doses of the $\mathrm{ET}_{\mathrm{A}}$ antagonist $\mathrm{ZD} 4054$ do not inhibit clearance of ET-1, and therefore that ZD4054 does not inhibit $\mathrm{ET}_{\mathrm{B}}$ in man. Through its specificity for $\mathrm{ET}_{\mathrm{A}}, \mathrm{ZD} 4054$ may offer advantages over other less specific $\mathrm{ET}_{\mathrm{A}}$ antagonists in the oncology setting. Any degree of binding to $\mathrm{ET}_{\mathrm{B}}$ has the potential to reduce the efficacy of $\mathrm{ET}_{\mathrm{A}}$ blockade strategies, both directly through inhibition of $\mathrm{ET}_{\mathrm{B}}$-mediated apoptosis and indirectly by reduction of ET-1 clearance, leading to a rise in levels of the $\mathrm{ET}_{\mathrm{A}}$ ligand, ET-1. Treatment with the selective $\mathrm{ET}_{\mathrm{A}}$ antagonist atrasentan (10 mg once daily for 28 days) resulted in a significant increase in plasma ET-1 levels in a study of patients with refractory adenocarcinomas (Carducci et al, 2002). Plasma levels of ET-1 rose linearly with increasing dose of atrasentan (dose range evaluated, $10-75 \mathrm{mg}$ ). This increase in plasma levels of ET-1 suggests reduced clearance of ET-1, an effect that could impair the efficacy of any $\mathrm{ET}_{\mathrm{A}}$-blocking strategy. The authors hypothesised that the rise in plasma ET-1 reported with atrasentan was the result of direct $\mathrm{ET}_{\mathrm{A}}$ blockade (Carducci et al, 2002). Although it is difficult to extrapolate between patients and healthy volunteers, evidence from the present study shows that blockade of $\mathrm{ET}_{\mathrm{A}}$ by ZD4054, which has no detectable affinity for $\mathrm{ET}_{\mathrm{B}}$ (at a concentration of $10 \mu \mathrm{M}$ ), does not result in elevated plasma levels of ET-1. Furthermore, the ability of atrasentan to increase plasma levels of ET-1 has been attributed to blockade of $\mathrm{ET}_{\mathrm{B}}$ (Nelson, 2003) and suggests that the system is highly sensitive to $\mathrm{ET}_{\mathrm{B}}$ blockade. To our knowledge, ZD4054 is the only endothelin receptor antagonist in clinical development that targets $\mathrm{ET}_{\mathrm{A}}$ and does not inhibit $\mathrm{ET}_{\mathrm{B}}$ at doses under clinical investigation.

In conclusion, volunteer studies and pre-clinical receptor-binding studies confirm that ZD4054 is a potent antagonist of $\mathrm{ET}_{\mathrm{A}}$, with no evidence of $\mathrm{ET}_{\mathrm{B}}$ blockade at doses upto $240 \mathrm{mg}$ in volunteers and at $10 \mu \mathrm{M}$ in vitro. This lack of affinity for $\mathrm{ET}_{\mathrm{B}}$ suggests that ZD4054 has the potential to block the multiple pathological processes in malignancy that are mediated by $\mathrm{ET}_{\mathrm{A}}$, while allowing the beneficial processes mediated by $\mathrm{ET}_{\mathrm{B}}$, such as apoptosis and clearance of ET1 , to proceed. Further studies to assess the clinical impact of specific $\mathrm{ET}_{\mathrm{A}}$ inhibition by ZD4054 in patients with cancer are ongoing.

\section{ACKNOWLEDGEMENTS}

We thank Susan Hasmall for valued editorial assistance with financial support from AstraZeneca.

\section{REFERENCES}

Bagnato A, Catt KJ (1998) Endothelins as autocrine regulators of tumor cell growth. Trends Endocrinol Metab 9: 378-383

Bagnato A, Spinella F (2003) Emerging role of endothelin-1 in tumor angiogenesis. Trends Endocrinol Metab 14: 44-50
Bagnato A, Tecce R, Di Castro V, Catt KJ (1997) Activation of mitogenic signaling by endothelin 1 in ovarian carcinoma cells. Cancer Res 57: 1306-1311 Battistini B, Chailler P, D'Orleans-Juste P, Briere N, Sirois P (1993) Growth regulatory properties of endothelins. Peptides 14: 385-399 
Bradbury RH, Bath C, Butlin RJ, Dennis M, Heys C, Hunt SJ, James R, Mortlock AA, Summer NF, Tang EK, Telford B, Whiting E, Wilson C (1997) New non-peptide endothelin-A receptor antagonists: synthesis, biological properties, and structure - activity relationships of 5-(dimethylamino)- $N$-pyridyl-, $-\mathrm{N}$-pyrimidinyl, - $\mathrm{N}$-pyridazinyl-, and $-\mathrm{N}$-pyrazinyl-1naphthalenesulfonamides. J Med Chem 40: 996-1004

Carducci MA, Nelson JB, Bowling MK, Rogers T, Eisenberger MA, Sinibaldi V, Donehower R, Leahy TL, Carr RA, Isaacson JD, Janus TJ, Andre A, Hosmane BS, Padley RJ (2002) Atrasentan, an endothelin-receptor antagonist for refractory adenocarcinomas: safety and pharmacokinetics. J Clin Oncol 20: 2171-2180

Cheng Y, Prusoff WH (1973) Relationship between the inhibition constant (Ki) and the concentration of inhibitor which causes 50 percent inhibition $\left(\mathrm{IC}_{50}\right)$ of an enzymatic reaction. Biochem Pharmacol 22: 3099-3108

Curtis N, Anderson E, Brooks N, Curwen J (2005) ZD4054 blocks ET-1stimulated phosphorylation of p44/42 mitogen-activated protein kinase and proliferation of osteoblast cells. Proc Am Assoc Cancer Res 46: 354 (abstract 1512)

Curtis N, Howard Z, Brooks N, Curwen J (2004) ZD4054 specifically inhibits endothelin A receptor-mediated anti-apoptotic effects, but not endothelin B receptor-mediated pro-apoptotic effects. Eur J Cancer Suppl 2: 27 (abstract 78)

Del Bufalo D, Di Castro V, Biroccio A, Varmi M, Salani D, Rosanò L, Trisciuoglio D, Spinella F, Bagnato A (2002) Endothelin-1 protects ovarian carcinoma cells against paclitaxel-induced apoptosis: requirement for Akt activation. Mol Pharmacol 61: 524-532

Dreicer R, Curtis N, Morris C, Wilson D, Hughes A, Le Maulf F, Howard Z, Brooks N, Curwen J (2005) ZD4054 specifically inhibits endothelin A receptor-mediated effects but not endothelin B receptor-mediated effects. Proc ASCO Multidisciplinary Prostate Cancer Sympos 153: 153 (abstract 237)

Kopetz ES, Nelson JB, Carducci MA (2002) Endothelin-1 as a target for therapeutic intervention in prostate cancer. Invest New Drugs 20: 173-182

Nelson JB (2003) Endothelin inhibition: novel therapy for prostate cancer. J Urol 170: S65-S68

Nelson J, Bagnato A, Battistini B, Nisen P (2003) The endothelin axis: emerging role in cancer. Nat Rev Cancer 3: 110-116

Nelson JB, Hedican SP, George DJ, Reddi AH, Piantadosi S, Eisenberger MA, Simons JW (1995) Identification of endothelin-1 in the pathophy- siology of metastatic adenocarcinoma of the prostate. Nat Med 1: $944-$ 949

Nelson JB, Nguyen SH, Wu-Wong JR, Opgenorth TJ, Dixon DB, Chung LW, Inoue $\mathrm{N}$ (1999) New bone formation in an osteoblastic tumor model is increased by endothelin-1 overexpression and decreased by endothelin A receptor blockade. Urology 53: 1063 - 1069

Okazawa M, Shiraki T, Ninomiya H, Kobayashi S, Masaki T (1998) Endothelin-induced apoptosis of A375 human melanoma cells. J Biol Chem 273: $12584-12592$

Pirtskhalaishvili G, Nelson JB (2000) Endothelium-derived factors as paracrine mediators of prostate cancer progression. Prostate 44: 77-87

Rolinski B, Geier SA, Sadri I, Klauss V, Bogner JR, Ehrenreich H, Goebel FD (1994) Endothelin-1 immunoreactivity in plasma is elevated in HIV-1 infected patients with retinal microangiopathic syndrome. Clin Investig 72: $288-293$

Rosanò L, Di Castro V, Spinella F, Natali PG, Bagnato A (2005) ZD4054, a specific antagonist of the endothelin A receptor, inhibits tumor growth and enhances cytotoxicity of paclitaxel in human ovarian carcinoma in vitro and in vivo. Proc Am Assoc Cancer Res 46: 1372 (abstract 5830)

Rosanò L, Varmi M, Salani D, Di Castro V, Spinella F, Natali PG, Bagnato A (2001) Endothelin-1 induces tumor proteinase activation and invasiveness of ovarian carcinoma cells. Cancer Res 61: 8340-8346

Spinella F, Rosano L, Di Castro V, Natali PG, Bagnato A (2002) Endothelin-1 induces vascular endothelial growth factor by increasing hypoxiainducible factor-1alpha in ovarian carcinoma cells. J Biol Chem 277: $27850-27855$

Spratt JC, Goddard J, Patel N, Strachan FE, Rankin AJ, Webb DJ (2001) Systemic $\mathrm{ET}_{\mathrm{A}}$ receptor antagonism with $\mathrm{BQ}-123$ blocks ET-1 induced forearm vasoconstriction and decreases peripheral vascular resistance in healthy men. Br I Pharmacol 134: 648-654

Strachan FE, Newby DE, Sciberras DG, McCrea JB, Goldberg MR, Webb DJ (2002) Repeatability of local forearm vasoconstriction to endothelin-1 measured by venous occlusion plethysmography. Br J Clin Pharmacol 54: $386-394$

Strachan FE, Spratt JC, Wilkinson IB, Johnston NR, Gray GA, Webb DJ (1999) Systemic blockade of the endothelin-B receptor increases peripheral vascular resistance in healthy men. Hypertension 33: $581-585$

Wilkinson IB, Webb DJ (2001) Venous occlusion plethysmography in cardiovascular research: methodology and clinical applications. Br J Clin Pharmacol 52: 631-646 